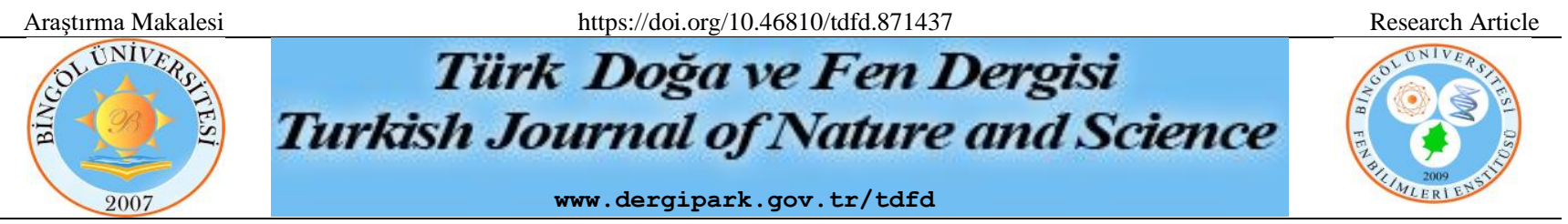

\title{
Şırnak İli Koşullarında Soya Bitkisinin II. Ürün Olarak Yetiştirilebilme Olanaklarının Araştırılması
}

\author{
Ferhat ÖZTÜRK ${ }^{1 *}$, Ferhat KIZILGEÇi ${ }^{2 *}$, Ahmet Konuralp ELIÇì ${ }^{3}$ \\ ${ }^{1}$ Şırnak Üniversitesi, Ziraat Fakültesi, Tarla Bitkileri Bölümü, Şırnak, Türkiye \\ ${ }^{2}$ Mardin Artuklu Üniversitesi, Kızıltepe Meslek Yüksekokulu, Bitkisel ve Hayvansal Üretim Bölümü, Mardin, Türkiye \\ ${ }^{3}$ Dicle Üniversitesi, Ziraat Fakültesi, Tarım Makinaları ve Teknolojileri Mühendisliği Bölümü, Diyarbakır, Türkiye \\ Ferhat ÖZTÜRK ORCID No: 0000-0002-2743-4285 \\ Ferhat KIZILGEÇI ORCID No: 0000-0002-7884-5463 \\ Ahmet Konuralp ELİÇĩN ORCID No:0000-0003-3240-4567 \\ *Sorumlu yazar: ferhat_kizilgeci@hotmail.com
}

(Alınış: 31.01.2021, Kabul: 19.04.2021, Online Yayınlanma: 25.06.2021)

\begin{abstract}
Anahtar
Kelimeler

Çeşit,

Yă̆ asidi,

Kalite,

Soya

fasulyesi
\end{abstract}

\begin{abstract}
Öz: Soya bünyesinde ihtiva ettiği besinler nedeniyle, insan ve hayvan beslenmesinde oldukça önemli bir besin maddesidir. $\mathrm{Bu}$ çalışma, Şırnak ilinin ikinci ürün soya yetiştiriciliğine uygunluğunun belirlenmesi amacıyla yürütülmüştür. Araştırmada farklı olgunlaşma grubunda yer alan 13 soya çeşidi tesadüf blokları deneme desenine göre üç tekerrürlü olarak 2019 yılında İdil ilçesinde kurulmuştur. Çalışmada bitki boyu, ilk meyve yüksekliği, boğum sayısı, meyve sayısı, tohum sayısı, 100 tohum ağılığı, protein oranı, tohum verimi, yağ oranı ve yağ asit içerikleri incelenmiştir. Çalışmanın varyans analizi sonuçlarına göre incelenen tüm özellikler yönünden çeşitler arası farklılıkların önemli düzeyde olduğu belirlenmiştir. Gapsoy 16, Planet ve Lider tane veriminde ön plana çıkan çeşitler olmuştur. Blaze ve Gapsoy 16 çeşitleri yüksek protein ihtiva ederken, Atakişi çeşidi en yüksek yağ oranına sahip olmuştur. Oleik asit içeriğinin Bravo çeşidinde, linoleik asit içeriği ise Lider çeşitlerinde en yüksek değere sahip olduğu belirlenmiştir. Araştırma sonucunda, yetişme periyodu ve incelenen özellikler bakımından Şırnak ili koşullarında ikinci ürün soya yetiştiriciliğinin başarıyla yapılabileceği ve Lider, Gapsoy 16, Planet çeşitlerinin ise en uygun çeşitler olduğu kanısına varılmıştır.
\end{abstract}

Investigation of Possibilities of Cultivating Soybean as Second Crop in Sirnak Conditions

Keywords Cultivar, Fatty acid, Quality, Soybean

\begin{abstract}
Soybean is a nutrient that has an important place in human and animal nutrition due to the nutrients it contains. This study was carried out to determine the suitability of Şırnak province for second crop soybean cultivation. In the study, 13 soybean varieties in different maturation groups were established with three replications according to randomized complete blocks design in Idil district in 2019. Plant height, first pod height, node number, pod number, seed number, 100 seed weight, seed yield, oil ratio, protein ratio and fatty acids were examined in the study. According to the results of the variance analysis of the obtained values, significant differences were determined among the genotypes in terms of all traits examined. In the present research, Gapsoy16, Planet and Lider were the prominent varieties in terms of grain yield. While Blaze and Gapsoy16 varieties contain high protein, Atakişi variety has the highest fat content. Oleic acid content is from Bravo variety, and linoleic acid content has the highest value in Lider varieties. As a result of the research, it was concluded that the second crop soybean cultivation can be successfully carried out in Şırnak province in terms of the growing period and the characteristics examined, and Lider, Gapsoy 16 and Planet varieties are the most suitable varieties.
\end{abstract}

\section{GíRiş}

Soya bünyesinde ihtiva ettiği besinler nedeniyle, insan ve hayvan beslenmesinde oldukça önemli bir besin maddesidir. Soya yağı bazı önemli yă̆ asitlerini içerdiğinden, gıda maddesi olarak insan sağlığı için oldukça önemlidir. Soya aynı zamanda sanayi sektörüne de hammadde kaynağı sağlamaktadır. 2018 yılında, Dünya bitkisel yağl1 tohum üretimi 569.4 milyon ton olup, üretimin \% 61.2'ü soyadan, \% 9.1'u ayçiçeğinden, \% 2.9'u çiğitten, \% 33.2'si palm, \% 15.4'ü kolzadan ve 
\% 11.8'i de diğer yağlı tohumlu bitkilerden karşılanmıştır [1]. Yağlı tohum üretiminde Amerika Birleşik Devletleri (ABD) ilk sırada yer almaktadır. ABD'yi Brezilya, Arjantin, Çin ve Hindistan takip etmektedir. Ülkemizde yağlı tohum üretimi 2018 yılı verilerine göre yaklaşık 4 milyon ton olmuştur [2]. Türkiye'nin yıllık soya ihtiyacı ise 2 milyon tonun üzerindedir. Yağlı tohum üretimi içerisinde soya üretimi 2020 y1lında, 352.950 dekar alanda 150.000 ton soya fasulyesi üretilerek dekara $425 \mathrm{~kg} / \mathrm{da}$ verim elde edilmiștir. Türkiye'nin soyadaki kendine yeterlilik oranı \% 4.7'dir. Ülkemizde toplam ham yağ üretimi 3 mil. ton olup, bunun \%72.7'si (2 mil. ton) yurt dışından ithal edilen yağlı tohumlardan karşılanırken, \% 27.3'ü (760 bin ton) ise yerli tohumlardan ve ham yağlardan karşılanmıştır. $\mathrm{Bu}$ durum, diğer bir ifadeyle soya üretimi yönüyle \% 93'lük bir açığımız olduğu anlamına gelmektedir ve bu açığı kapatmak için yaptığımız ithalatın ülkemize maliyeti yaklaşık yıllık 3.45 milyar dolardır (petrolden sonra en fazla). Şırnak ili yağ bitkileri tarımı için elverişli koşullara sahip olmasına karşın, 2017 verilerine göre yağ bitkileri üretim alanı 5000 da ve üretim miktarı 2.2 bin ton ile sınırlı kalmıştır [2]. Geniş bir arazi potansiyeli ve yağ bitkileri üretimi bakımından uygun ekolojik koşullara sahip olan Şırnak ilinde, yağ bitkileri üretimi oldukça düşük düzeydedir. Soya üretimi ile ilgili Şırnak ilinde son yıllarda herhangi bir üretim faaliyeti görülmemektedir. Bundan dolayı, yüksek verim ile birlikte kaliteli çeşitlerin saptanması ve ıslahı ülkemiz ve bölgemiz için önemlidir. Bölgemizde yetiştirilebilen çeşit yağ içeriği ve yağ asit içeriği de, özellikle sanayi sektörü acısından da önem arz etmektedir. Soya yüksek verime sahip önemli bir bitki olup, uygun çeşit seçimi ve tohum kalitesi özellikle verim ve diğer verim öğelerini etkileyen en önemli faktörlerdir. $\mathrm{Bu}$ nedenle ekim zamanına uyumlu çeşit seçimi ve yüksek çimlenme kabiliyetine sahip tohumlar kullanılmalıdır. Aksi takdirde uygulama yöntemlerinin en uygun olması durumunda dahi, en yüksek verimi elde etmek mümkün olmamaktadır. $\mathrm{Bu}$ araştırmanın amac1; Güneydoğu Anadolu Bölgesinde artan sulama olanaklarından dolayı, Şırnak ilinde soya bitkisinin ikinci ürün olarak yetiştiriciliğine uygunluğu ve çeşit tespitinin belirlenmesi amac1yla yürütülmüsstür.

\section{MATERYAL VE METOT}

\subsection{Araştırmada Kullanılan Materyaller}

Mevcut çalışmada, farklı olgunlaşma grubunda yer alan 13 soya çeşidi (Bravo, Arısoy, Atakişi, Gapsoy, Nova, Planet, Lider, Blaze, Asya, Anp2018, Nazlican, Türksoy, Adasoy) materyal olarak kullanılmıştır. Araştırmada kullanılan soya çeşitlerine ait bilgiler Tablo 1 'de verilmiştir.

Tablo 1. Araştırmada kullanılan çeşitlere ait özellikler

\begin{tabular}{|c|c|c|c|c|}
\hline Çeşit adı & $\begin{array}{l}\text { Olgunlaşma } \\
\text { Grubu }\end{array}$ & Çiçek Rengi & Hilum Rengi & Yetiştirici Kuruluş \\
\hline Bravo & III & Mor & Koyu kahverengi & ProGen \\
\hline Arısoy & III & Beyaz & K1z1l & Atlas Tohumculuk \\
\hline Atakişi & III & Beyaz & Koyu kahverengi & Atlas Tohumculuk \\
\hline Gapsoy16 & III & Beyaz & Sar1 & GAP Tarımsal Araştırma Enstitüsü Müdürlüğü \\
\hline Nova & III & Beyaz & Kahverengi & May Tohum \\
\hline Planet & III & Mor & Siyah & Agrova Tohum \\
\hline Lider & III & Beyaz & Kahverengi & ProGen \\
\hline Blaze & IV & Mor & Siyah & May Tohum \\
\hline Asya & III & Mor & Kahverengi & ProGen \\
\hline Anp2018 & III & Menekşse & Sar1 & $\begin{array}{l}\text { Doğu Akdeniz Tarımsal Araştırma Enstitüsü } \\
\text { Müdürlüğü }\end{array}$ \\
\hline Nazlican & IV & Mor & Sar1 & $\begin{array}{l}\text { Doğu Akdeniz Tarımsal Araştırma Enstitüsü } \\
\text { Müdürlüğü }\end{array}$ \\
\hline Türksoy & IV & Mor & Kahverengi & $\begin{array}{c}\text { Doğu Akdeniz Tarımsal Araştırma Enstitüsü } \\
\text { Müdürlüğü }\end{array}$ \\
\hline Adasoy & IV & Beyaz & Kahverengi & $\begin{array}{c}\text { Doğu Akdeniz Tarımsal Araştırma Enstitüsü } \\
\text { Müdürlüğü }\end{array}$ \\
\hline
\end{tabular}

\subsection{Deneme Yeri ve Özelliği}

Çalıșma, Șırnak ili İdil ilçesinde ikinci ürün koşullarında tesadüf blokları deneme desenine göre üç tekerrürlü olarak 2019 yılında yürütülmüştür. Araştırma alanında ön bitki olan buğdayın hasadından sonra deneme alanı pullukla sürülüp diskaro çekilmiştir. Diskarodan sonra arazi sulanıp tava getirildikten sonra araştırma alanı tohum yatağı ekime hazır hale getirilmesi için kültivatörle toprak işlemesi yapılmıştır. Ekim öncesinde dekara 20 kg DAP (18-46) gübresi ve ilk sulamadan önce de $20 \mathrm{~kg} \mathrm{da}^{-1}$ amonyum nitrat (\%26) gübresi uygulanmıştır. Deneme parselleri $6.0 \mathrm{~m} \times 4.2 \mathrm{~m}=25.2 \mathrm{~m}^{2}$, her parsel 6 sirada oluşturulacak şekilde ve ekim sıklığ $70 \mathrm{~cm}$ x $5 \mathrm{~cm}$ olarak tesis edilmiştir. Ekim işlemi 19 Haziran 2019 tarihinde gerçekleştirilmiştir. Yetişme periyodunda tüm gerek duyulan bakımlar zamanında ve tekniğine uygun olarak yapılmıştır. Bitkinin ihtiyacına göre çiçeklenme dönemine kadar yağmurlama ve karık usulü olmak üzere toplamda 7 sulama uygulanmıştır. Hasat, çeşitlerin olgunlaşma ve nem durumlarına göre Ekim ayının 2. haftasında elle yapılmıștır. 
Deneme süresince aylık ortalama sicaklık; 21.6-33.0 ${ }^{\circ} \mathrm{C}$ arasında değișim göstermiştir. En yüksek hava sıcaklığı $33.0{ }^{\circ} \mathrm{C}$ ile Ağustos ayında görülmüştür. Yağış verilerine göre, araştırma süresince yağış miktarları 0.0-34.2 mm arasında gerçekleşmiştir (Şekil 1). Yağışın yetersiz olmasından dolayı ihtiyaç duyulan su sulamayla karşılanmıştır.
Deneme alanının toprak özelliği; killi- tınlı yapıda olup, $\mathrm{pH}^{\prime} 18.12$, tuzluluk sorunu bulunmayan, kireç içeriği \%10.8 ile orta kireçli, organik madde içeriği $\% 0.71$, fosfor miktarı $2.75 \mathrm{~kg} \mathrm{da}^{-1}$ ve potasyum içeriği yönünden oldukça yüksek olduğu saptanmıştır.

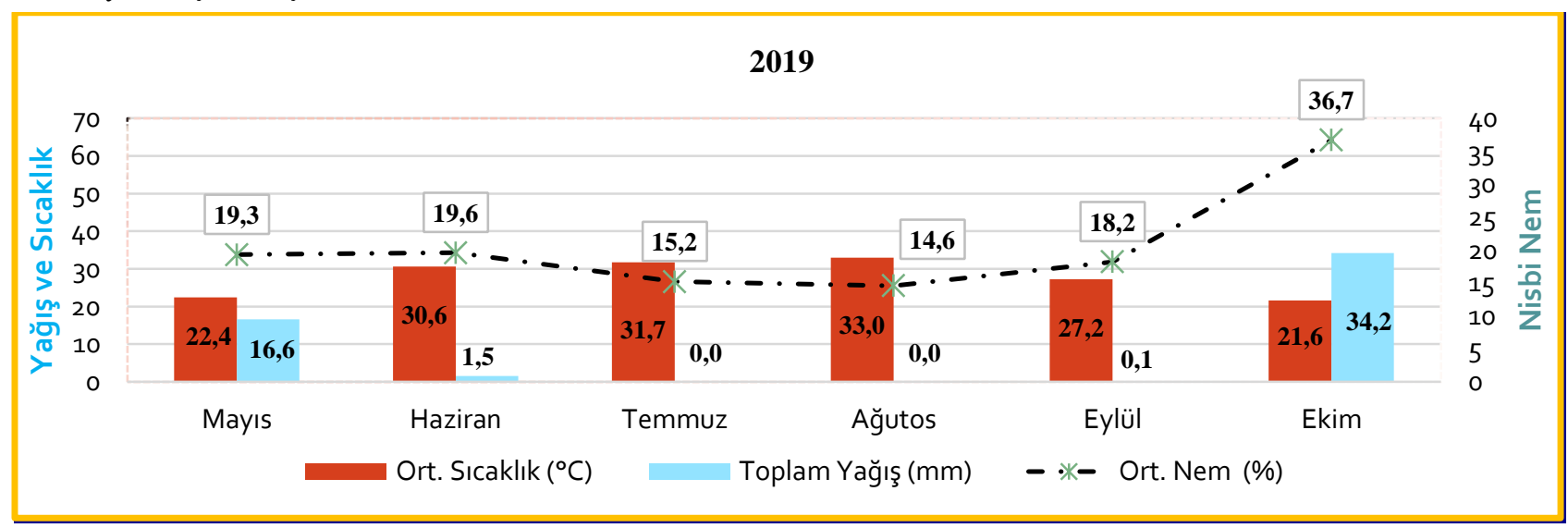

Şekil 1. Çalışmanın yürütüldüğü döneme ait iklim verileri

\section{3. İncelenen Özellikler:}

2.3.1. Bitki boyu (cm): Her parselin orta iki sırasından rastgele seçilen hasat olgunluğuna gelmiş 10 bitkinin, en tepedeki noktası ile toprak yüzeyi arasındaki mesafe ölçülüp ortalamaları alındı.

2.3.2. İlk meyve yüksekliği (cm): Rastgele seçilen hasat olgunluğuna gelmiş 10 bitkide, toprak yüzeyine en yakın olan meyvenin, toprak yüzeyinden yüksekliği ölçülüp ortalamaları alındı.

2.3.3. Boğum sayısı (adet/bitki): Rastgele seçilen hasat olgunluğuna gelmiş 10 bitkide, boğumlar sayılarak ve ortalamaları alınd.

2.3.4. Meyve sayısı (adet/bitki): Rastgele seçilen hasat olgunluğuna gelmiş 10 bitkide, bitki üzerinde bulunan tüm meyveler sayılıp ortalamaları alındı.

2.3.5. Tohum sayısı (adet/bitki): Rastgele seçilen hasat olgunluğuna gelmiş 10 bitkide, bitki üzerinde bulunan tüm tohumlar sayılıp ortalamaları alınmıştır.

2.3.6. 100 tohum ağırlığı (g): Her parselden tesadüfen alınan tohumlar, tohum sayma makinasından geçirilerek elde edilen $4 \times 100$ adet tohum tartılıp, ortalama sonucunda 100 tane ağırlığı belirlenmiştir.

2.3.7. Tane verimi $\left(\mathrm{kg} \mathrm{da}^{-\mathbf{1}}\right)$ : Uygulama parsellerinin orta iki sırası hasat edilip, bitkiler harman edilerek temizlenen tohumlar tartım sonucu parsel verimi ve parsel veriminden yararlanarak dekar başına $\left(\mathrm{kg} \mathrm{da}^{-1}\right)$ tane verimi hesaplanmıştır.

2.3.8. Yă oranı (\%): Her parselden elde edilen tohumlar öğütme işlemine tabi tutulduktan sonra elde edilen örneklerden $5 \mathrm{~g}$ alınarak, Bilim ve Teknoloji
Uygulama ve Araştırma Merkezi laboratuvarında, UVVIS-NIR Spektrofotometre cihaziyla analizler yapılmıştır.

2.3.9. Protein oranı (\%): Her parselden alınan ögütülmüş tohum örneklerinden $5 \mathrm{~g}$ alınarak, Bilim ve Teknoloji Uygulama ve Araştırma Merkezi laboratuvarında, UV-VIS-NIR Spektrofotometre cihazıyla analiz edilmiştir.

2.3.10. Yağ asitleri içeriği (\%): Her parselden alınan ögütülmüş tohum örneklerinden $5 \mathrm{~g}$ alınarak, Şırnak Üniversitesi Merkezi Araştırma Laboratuvarı, GC-MS cihazıyla analizler yapıldı.

2.3.11. İstatistiksel analiz: Araştırmada elde edilen verilerin varyans analizi ve korelasyon analizi JMP 10 istatistik analiz programında yapıldı. Ortalamalar arası farklılıklar LSD $\% 5$ çoklu karşılaştırma testi uygulanmıştır.

\section{BULGULAR}

\subsection{Bitki Boyu (cm)}

Araştırma sonucunda, bitki boyu bakımından çeşitler arasında istatistiksel olarak $\mathrm{P}<0.01$ düzeyinde önemli farklılıklar belirlenmiştir (Tablo 2). Soya çeşitleri arasında, en yüksek bitki boyu Planet $(112.51 \mathrm{~cm})$ ve Gapsoy16 (108.42 cm) çeşitlerinden, en düşük bitki boyu ise Bravo $(64.55 \mathrm{~cm})$ çeşidinde belirlenmiştir (Tablo 2). [3], tohum verimi ile bitki boyu arasında pozitif ve önemli bir ilișki olduğunu bildirilmiștir. Bitki boyu soya için önemli bir verim unsurudur. Çeşitler arasında görülen bitki boyu farklılığının, çeşitlerin genetik yapılarındaki farklılık ve farklı olgunlaşma gruplarından olmasından ileri geldiği düşünülmektedir. [4], ikinci ürün çalışmasında bitki boyu değerlerinin 
42.0-73.6 cm arasında olduğunu belirtmişlerdir. Ayrıca soya bir kısa gün bitkisi olması nedeniyle, Haziran ayından itibaren günlerin kısalmaya başlamasından dolayı, Haziran ayının son haftasında yapılan geç ekimlerde özellikle kısa gün koşullarının etkili olması nedeniyle vejetatif büyüme gerilemekte ve bunun sonucunda bitki boyunda kısalma söz konusu olmaktadır. [5], ekim zamanı geciktikçe bitki boyunda kısalma olduğunu belirtmişlerdir.

\section{2. İlk Meyve Yüksekliği (cm)}

Soya çeşitleri arasında, ilk meyve yüksekliği bakımından istatistiki olarak önemli derecede farklılıklar oluşmuştur (Tablo 2). Araştırmada, en yüksek ilk meyve yüksekliği $24.60 \mathrm{~cm}$ ile Adasoy çeşidinden elde edilirken, en düşük ilk meyve yüksekliği Blaze $(12.0 \mathrm{~cm})$, Asya $(12.46 \mathrm{~cm})$ ile Nova (12.73 cm) çeşitlerinden elde edilmiştir (Tablo 2). Soya yetiştiriciliğinde, baklaların toprak yüzeyine yakın olması soya tarımını olumsuz yönde etkilemektedir. Birçok araştırıcı çalışmalarında soyanın hasat edilirken toprak yüzeyine yakın olan meyvelerin hasat edilememesinden dolayı önemli miktarda hasatta verim kaybına neden olduğunu rapor etmişlerdir [5-8]. $\mathrm{Bu}$ nedenle ilk baklaların toprak yüzeyinden yüksek olması istenilen bir özelliktir. [9], soyada ekim zamanının kalite ve agronomik özellikleri belirlemek üzerine yapmış oldukları çalışmada, ekim zamanı geciktikçe ilk bakla yüksekliklerinde azalma olduğunu ve ana ürün koşullarında ilk meyve yüksekliği $19.3 \mathrm{~cm}$ iken, II. ürün şartlarında ise ortalama $17.9 \mathrm{~cm}$ olarak belirlenmiş ve ana ürün (erken ekim) soyada uzun gün koşulları özellikle vejetatif gelişmeyi etkilerken, ikinci ürün soya ekiminde ise kısa gün koşullarının etkili olduğu belirtilmiştir. İkinci ürün olarak 21 Hazirandan sonra yapılan geç ekimlerde ise kısa gün koşullarının etkili olması ile birlikte artan sıcaklık ortalamalarından dolayı, çiçeklenme erken başlamakta ve bundan dolayı da ilk meyveler toprağa yüzeyine yakın olarak oluşmaktadır [10]. [11], ilk meyve yüksekliğinin 7.40$11 \mathrm{~cm}$ arasında değiştiğini belirtmiştir.

Tablo 2. Çalışmada incelenen soya çeşitlerine ait verim ve verim unsurlarına ait ortalama değerleri ve varyans analizi sonuçları

\begin{tabular}{|c|c|c|c|c|c|c|c|}
\hline Genotip & $\begin{array}{c}\text { Bitki } \\
\text { Boyu } \\
(\mathbf{c m})\end{array}$ & $\begin{array}{c}\text { İlk Meyve } \\
\text { Yüksekliği } \\
(\mathrm{cm})\end{array}$ & $\begin{array}{c}\text { Boğum Sayısı } \\
\text { (adet/bitki) }\end{array}$ & $\begin{array}{c}\text { Meyve Sayısı } \\
\text { (adet/bitki) }\end{array}$ & $\begin{array}{c}\text { Tohum sayısı } \\
\text { (adet/bitki) }\end{array}$ & $\begin{array}{c}100 \text { Tohum } \\
\text { Ağırlığı } \\
\text { (g) }\end{array}$ & $\begin{array}{c}\text { Tane Verimi } \\
\left(\mathrm{kg} \mathrm{da}^{-1}\right)\end{array}$ \\
\hline Adasoy & $91.88 \mathrm{bc}$ & $24.60 \mathrm{a}$ & $18.16 \mathrm{a}$ & $57.93 \mathrm{ab}$ & $149.16 \mathrm{ab}$ & $16.48 b-e$ & $386.12 \mathrm{~cd}$ \\
\hline Anp2018 & $82.27 \mathrm{de}$ & $18.86 b$ & $17.16 \mathrm{abc}$ & $44.63 \mathrm{cde}$ & 105.90def & $15.82 \mathrm{de}$ & $332.48 \mathrm{~g}$ \\
\hline Arisoy & $80.82 \mathrm{e}$ & $17.83 \mathrm{~b}$ & $16.40 \mathrm{abc}$ & 42.26def & $93.53 \mathrm{fg}$ & $15.88 \mathrm{de}$ & $387.90 \mathrm{~cd}$ \\
\hline Asya & $82.76 \mathrm{de}$ & $12.46 \mathrm{c}$ & $14.66 \mathrm{~cd}$ & $52.60 \mathrm{bcd}$ & 121.70cde & $16.30 \mathrm{cde}$ & $358.49 \mathrm{ef}$ \\
\hline Atakişi & $88.57 \mathrm{~cd}$ & $18.55 b$ & $14.93 \mathrm{~cd}$ & $55.20 \mathrm{abc}$ & $158.64 \mathrm{a}$ & $16.15 \mathrm{cde}$ & 375.59de \\
\hline Blaze & $91.79 b c$ & $12.40 \mathrm{c}$ & $13.43 \mathrm{~d}$ & $67.30 \mathrm{a}$ & $168.30 \mathrm{a}$ & $16.48 b-e$ & $331.15 \mathrm{~g}$ \\
\hline Bravo & $64.55 \mathrm{f}$ & $13.80 \mathrm{bc}$ & $10.80 \mathrm{e}$ & $29.90 \mathrm{f}$ & $72.23 \mathrm{~g}$ & $16.63 \mathrm{bcd}$ & $273.81 \mathrm{~h}$ \\
\hline Gapsoy16 & $108.42 \mathrm{a}$ & $17.93 \mathrm{~b}$ & $17.76 \mathrm{ab}$ & $66.03 \mathrm{a}$ & $159.63 \mathrm{a}$ & $17.71 \mathrm{a}$ & $417.45 \mathrm{a}$ \\
\hline Lider & $79.86 \mathrm{e}$ & $13.86 \mathrm{bc}$ & $15.30 \mathrm{bcd}$ & $34.40 \mathrm{ef}$ & 96.07efg & $15.84 \mathrm{de}$ & $394.83 \mathrm{bc}$ \\
\hline Nazlican & $94.46 \mathrm{bc}$ & $17.26 \mathrm{bc}$ & $15.50 \mathrm{bcd}$ & $48.19 \mathrm{bcd}$ & $125.52 \mathrm{bcd}$ & $16.14 \mathrm{cde}$ & $345.35 \mathrm{fg}$ \\
\hline Nova & $94.26 \mathrm{bc}$ & $12.73 \mathrm{c}$ & $15.36 \mathrm{bcd}$ & $43.86 \mathrm{cde}$ & $127.40 \mathrm{bcd}$ & $15.64 \mathrm{e}$ & $390.49 \mathrm{~cd}$ \\
\hline Planet & $112.51 \mathrm{a}$ & $18.86 \mathrm{~b}$ & $15.40 \mathrm{bcd}$ & $55.90 \mathrm{abc}$ & $144.32 \mathrm{abc}$ & $17.30 \mathrm{ab}$ & $410.03 \mathrm{ab}$ \\
\hline Türksoy & $98.15 b$ & $15.46 \mathrm{bc}$ & $16.90 \mathrm{abc}$ & $46.63 \mathrm{~b}-\mathrm{e}$ & 110.66 def & $16.97 \mathrm{abc}$ & $333.79 \mathrm{~g}$ \\
\hline Ortalama & 90.02 & 16.51 & 15.52 & 49.60 & 125.62 & 16.41 & 371.97 \\
\hline \multicolumn{8}{|c|}{ Varyans } \\
\hline Genotip & $* *$ & $* *$ & $* *$ & $* *$ & $* *$ & $*$ & $* *$ \\
\hline $\mathrm{CV}(\%)$ & 4.4 & 17.7 & 9.7 & 15.2 & 12.4 & 3.3 & 3.1 \\
\hline
\end{tabular}

\subsection{Boğum Sayısı (Adet/Bitki)}

Boğum sayısı bakımından çeşitler arasındaki farklılık istatistiksel olarak önemli görülmüştür (Tablo 2). Boğum sayısı 10.80-18.16 adet arasında değişim göstermiştir. En fazla boğum sayısı Adasoy (18.16 adet) genotipinde belirlenirken, en az Boğum sayısı ise 10.80 adet ile Bravo genotipinde belirlenmiştir (Tablo 2). Boğum sayısı bakımından görülen farklılığın, kullanılan çeşidin erkenci ya da geçci olmasına bağlı olduğu belirtilmiştir [12].

\subsection{Meyve Sayısı (Adet/Bitki)}

Meyve sayısı bakımından çeşitler arasında istatistiksel olarak önemli farklılık görülmüştür (Tablo 2). Araştırmada en yüksek meyve sayısı Gapsoy16 (66.03 adet/bitki) ile Blaze (67.30 adet/bitki) çeşitlerinden belirlenirken, en düşük meyve sayısı ise Bravo (29.30 adet/bitki) çeşidinde belirlenmiştir (Tablo 2). Soyada meyve sayısı verimle önemli ve yakın ilişkili olup, bu nedenle yüksek meyve sayısı istenen bir parametredir. Meyve sayısı, çeşitlerin genetik yapılarındaki farklılıktan ve ekim zamanından (erken-geç) dolayı değişim gösterebilmektedir [13]. $\mathrm{Bu}$ çalışmamız sonucunda elde edilen veriler, diğer araştırmacıların bulgularıyla karşılaştırıldığında, [14] daha yüksek, [15] 'ın bulguları ile benzerlik göstermiştir.

\subsection{Tohum Sayısı (Adet/Bitki)}

Bitkide tohum sayısı bakımından çeşitler arasında istatistiksel olarak önemli farklılık görülmüştür (Tablo 2). En fazla tohum sayısına sahip genotipler Blaze 
(168.30 adet/bitki), Gapsoy (159.63 adet/bitki) ile Atakişi (158.64 adet/bitki) çeşitlerinden elde edilirken, en düşük tohum sayısı ise Bravo (72.23 adet/bitki) çeşidinde belirlenmiştir (Tablo 2). Tohum sayısı verimle olumlu bir ilişkiye sahip olan bir özelliktir. [16], ekim zamanın gecikmesiyle beraber tohum sayısında azalma olduğunu belirtmiştir.

\section{6. $\quad 100$ Tohum A Ăırlığı (g)}

100 tohum ağırlığ bir göstergesidir. Araştırmada istatistiksel olarak soya çeşitleri arasında önemli farklılıkların olduğu belirlenmiştir (Tablo 2). En yüksek değer Gapsoy (17.71 g) çeşidinde elde edilirken, en düşük tohum ağırlığı $15.64 \mathrm{~g}$ ile Nova çeşidinde tespit edilmiştir (Tablo 2). 100 tane ağırlığı bakımından çeşitler arasındaki görülen farklılığın, farklı genetik yapılara sahip oluşu ve ekolojik şartlarda farklı şekilde etkilenmelerinden kaynaklı olduğu söylenebilir. [15], bin tane tohum ağırlıklarının 176.0-194.0 g arasında değişim gösterdiğini belirtmiştir. [17], 1000 tane ağırlığını 124.0-153.0 g arasında belirlemiştir. Ayrıca bazı araştırmacılar tarafından önceki yıllarda yapılan çalışmalarında elde ettikleri sonuçlar, çalışmamızda elde dilen sonuçlardan daha yüksek olduğu görülmüştür [18-20].

\subsection{Tane Verimi $\left(\mathrm{kg} \mathrm{da}^{-\mathbf{1}}\right)$}

Tane verimine ait varyans analizi sonuçlarına göre; genotipler arasinda istatistiksel olarak $\mathrm{P} \leq 0.01$ düzeyinde önemli farklılıklar görülmüştür (Tablo 2).

Araştırmamız sonucunda en yüksek verim Gapsoy16 (417.45 $\mathrm{kg} \mathrm{da}^{-1}$ ) genotipinde elde edilirken, en düşük verim ise Bravo (273.81 $\left.\mathrm{kg} \mathrm{da}^{-1}\right)$ genotipinde elde edilmiştir (Tablo 2). Soya tohum verimi; çeşide ve uygulanan kültürel yöntemlere göre farklılık göstermektedir. Soyada tohum verimi; Günlük üretim (Fotosentez-Solunum) $\times$ Üretim yapılan gün sayısı ile belirtilmektedir [5]. Bu durumda erken ekimlerde gün uzunluğunun fazla olmasından dolayı, bitki daha fazla fotosentez yapmasından ötürü günlük verim de artmaktadır. Verim üzerine bitki kalıntılarının etkisi, ürün kalıntısının çeşidine, miktarına ve oranına göre değişmektedir [21]. Ayrıca [22], geç yapılan ekimden elde edilen tohum veriminin erken ekime göre \% 14.5 daha yüksek olduğunu belirlemiş olmakla birlikte, [23] ve [24], ekimin gecikmesi durumunda tohum veriminde azalma meydana geldiğini belirtmektedirler. Geç ekim nedeniyle tohum veriminde meydana gelen azalışın nedeninin geç ekimlerde meyve sayısı ve tohum sayısının düşmesine neden olan vejetatif ve generatif gelişme safhalarının ve özellikle tohum dolum süresinin daha kısa olmasından kaynaklandığ ileri sürülmektedir [25].

\subsection{Yă̆ Oranı (\%)}

Yağ oranına ait verilere ilişkin elde edilen varyans analiz sonuçlarına göre (Tablo 3), genotipler arasında istatistiksel olarak önemli farklılıklar görülmüştür. Araştırmamızda en yüksek yağ oranı Atakişis (\%24.81) genotipinde belirlenmiştir. En düşük yağ oranı ise Blaze (\%18.91) genotipinde belirlenmiştir (Tablo 3). En yüksek yağ içeriği \%23.83-22.86 ile Arısoy ve Blaze çeşitlerinde görülürken, diğer çeşitlerde ise yağ oranı \%20.16-20.66 değerleri arasında değişim göstermiştir. [26], [27] ve [28] soya yağ oranı çeşitlere göre farklılık gösterebileceğini belirtmişleridir. Ekim zamanının soyanın büyüme ve gelişmesini etkileyerek, tohumdaki protein, yağ, karbonhidrat ve diğer kimyasal bileşiklerin içeriğini etkilemektedir [29-31]. Geç ekim ile karşılaştırıldığında erken ekimde yağ oranında yaklaşık \%16 kadar artış sağlandığı, ekim zamanının gecikmesi ile yă̆ oranı azalmaktadır [30,32]. [31], farklı ekim zamanlarında yağ oranında meydana gelen farklılığın tohum dolum dönemindeki sıcaklık farkından kaynaklandığını bildirilmişlerdir. Protein oranı ile yağ oranı arasında zıt bir ilişki olduğu göz önüne alındığında [25], geç yapılan ekimlerde R5-R7 safhasındaki düşük sıcaklıklar protein oranının az da olsa düşmesine, yağ oranının ise daha yüksek olmasına neden olduğu düşünülmektedir. Bununla birlikte, R5R6 safhasında meydana gelen yüksek sıcaklıkların genellikle tohum yağ içeriğini düşürdüğü bilinmektedir. Daha önce yapılan birçok çalışmada, ekimin gecikmesi ile yağ oranının arttığı belirtilmesine rağmen, [33], yağ içeriği üzerine ekim zamanlarının etkisinin önemli olmadığını, [22] ise, ekimin gecikmesi ile tohum olgunlaşma dönemine denk gelen daha düşük sıcaklıklar yağ oranının erken ekime göre daha yüksek olmasına neden olduğunu belirtmişlerdir. [11], çeşitler arasında yağ oranı bakımından önemli bir farklılığın olmadığını belirtmiştir.

\subsection{Protein Oranı (\%)}

Protein oranı bakımından Tablo 3 incelendiğinde, çeşitler arasında istatistiki olarak önemli farklılık olduğu görülmüştür. En yüksek protein oranı Blaze (\%38.46) çeşidinden elde edilirken, en düşük protein oranı ise Anp2018 (\%32.74) genotipinde belirlenmiştir (Tablo 3). Çeşitler arasında protein oranı bakımından görülen farklılık çeşitlerin farklı genetik yapıda olmalarından kaynaklanmaktadır. [33], protein içeriği üzerine ekim zamanlarının etkisinin önemli olmadığı, [34], [31] ise, ekim zamanının gecikmesi ile protein oranında bir artış meydana geldiği, [32] ise soya ekiminin Mayıs ortasından Haziran ortasına geciktirilmesi ile protein oranında herhangi bir farkl1lık görülmediğini belirtmektedirler. Bununla birlikte, 1 ş1k kullanım etkinliğinin ekimin gecikmesi ile azaldığ [35], generatif safhada 1 şık alım miktarının bitki yapraklarındaki azot miktarını etkilediği, vejetatif organlarda biriken azotun önemli bir kısmının meyveye taşındığı, yaprak ve saplardan meyveye azot taşınımının 1şık kullanım etkinliği yüksek olan bitkilerde daha fazla olduğu ileri sürülmekte [36] ve bu etkenler nedeniyle farklı ekim zamanına göre protein oranında farklılık görülmesine neden olacaktır. [11], çeşitler arasında protein oranı bakımından farklılık olduğunu ve bu farklılığın genetik yapılarından ve çevresel faktörlerden kaynaklı olabileceğini belirtmiştir. 
Tablo 3. Çalışmada incelenen soya çeşitlerinin protein, yağ ve yağ asidi içeriklerinin ortalama değerleri ve varyans analizi sonuçları

\begin{tabular}{|c|c|c|c|c|c|c|c|}
\hline Genotip & $\begin{array}{c}\text { Yağ Oranı } \\
(\%)\end{array}$ & Protein (\%) & $\begin{array}{c}\text { Oleik } \\
(\%)\end{array}$ & $\begin{array}{c}\text { Linoleik } \\
(\%)\end{array}$ & $\begin{array}{c}\text { Linolenik } \\
(\%)\end{array}$ & $\begin{array}{c}\text { Palmitik } \\
(\%)\end{array}$ & $\begin{array}{c}\text { Stearik } \\
(\%)\end{array}$ \\
\hline Adasoy & $21.79 \mathrm{~d}$ & $34.85 \mathrm{~h}$ & $27.09 \mathrm{f}$ & $39.70 \mathrm{e}$ & $10.54 \mathrm{c}$ & $11.44 \mathrm{~h}$ & $8.10 \mathrm{ab}$ \\
\hline Anp2018 & $21.48 \mathrm{e}$ & $32.74 \mathrm{j}$ & $27.65 \mathrm{e}$ & $39.98 \mathrm{~d}$ & $10.23 \mathrm{f}$ & $12.54 \mathrm{a}$ & $7.34 \mathrm{ef}$ \\
\hline Arisoy & $19.21 \mathrm{~h}$ & $35.10 \mathrm{~g}$ & $27.52 \mathrm{e}$ & $39.50 \mathrm{f}$ & $10.64 \mathrm{~b}$ & $12.44 \mathrm{~b}$ & $7.59 \mathrm{~d}$ \\
\hline Asya & $23.08 \mathrm{~b}$ & $36.78 \mathrm{c}$ & $27.09 f$ & $40.01 \mathrm{~d}$ & $10.18 \mathrm{~g}$ & $12.54 \mathrm{a}$ & $7.48 \mathrm{de}$ \\
\hline Atakişi & $24.81 \mathrm{a}$ & $34.82 \mathrm{~h}$ & $26.31 \mathrm{~g}$ & $40.02 \mathrm{~d}$ & $10.42 \mathrm{~d}$ & $12.11 \mathrm{~d}$ & $8.02 b$ \\
\hline Blaze & 18.291 & $38.46 \mathrm{a}$ & $27.88 \mathrm{~d}$ & $40.11 d$ & $10.11 \mathrm{~h}$ & $11.87 \mathrm{e}$ & $7.56 \mathrm{~d}$ \\
\hline Bravo & $19.06 \mathrm{~h}$ & $36.73 \mathrm{c}$ & $29.58 \mathrm{a}$ & $38.79 \mathrm{~h}_{1}$ & $9.55 \mathrm{k}$ & $12.07 \mathrm{~d}$ & $7.38 \mathrm{ef}$ \\
\hline Gapsoy16 & $19.51 \mathrm{~g}$ & $37.12 b$ & $27.66 \mathrm{e}$ & $40.63 \mathrm{a}$ & $11.25 \mathrm{a}$ & $11.60 \mathrm{~g}$ & $8.25 a$ \\
\hline Lider & $20.80 \mathrm{f}$ & $35.21 \mathrm{f}$ & $28.23 \mathrm{c}$ & 38.661 & $9.68 \mathrm{j}$ & $11.86 \mathrm{e}$ & $7.23 \mathrm{f}$ \\
\hline Nazlican & $22.44 \mathrm{c}$ & 34.141 & $28.49 b$ & $39.02 \mathrm{~g}$ & $10.10 \mathrm{~h}$ & $12.31 \mathrm{c}$ & $7.78 \mathrm{c}$ \\
\hline Nova & $20.55 \mathrm{f}$ & $35.89 \mathrm{f}$ & $27.09 \mathrm{f}$ & $40.45 b$ & $10.28 \mathrm{e}$ & $12.31 \mathrm{c}$ & $7.56 \mathrm{~d}$ \\
\hline Planet & $21.44 \mathrm{e}$ & $36.24 d$ & $28.13 \mathrm{c}$ & $40.27 \mathrm{c}$ & 9.881 & 10.881 & $8.18 \mathrm{a}$ \\
\hline Türksoy & $21.42 \mathrm{e}$ & $34.82 \mathrm{~h}$ & $28.25 \mathrm{c}$ & $38.94 \mathrm{gh}$ & $10.31 \mathrm{e}$ & $11.70 \mathrm{f}$ & $8.19 a$ \\
\hline Ortalama & 21.07 & 35.61 & 27.77 & 39.70 & 10.24 & 11.97 & 7.74 \\
\hline \multicolumn{8}{|c|}{ Varyans } \\
\hline Genotip & $* *$ & $* *$ & $* *$ & $* *$ & $* *$ & $* *$ & $* *$ \\
\hline CV (\%) & 0.8 & 0.8 & 0.3 & 0.2 & 0.2 & 0.4 & 1.2 \\
\hline
\end{tabular}

**, $\mathrm{P} \leq 0,01$ seviyesinde önemlidir.

\subsection{Yă̆ Asitleri (Oleik, Linoleik, Linolenik, Palmitik ve Stearik asit)}

Yağ asitleri bakımından çeşitler arasında istatistiksel olarak önemli farklılık olduğu, araştırmaya alınan soya çeşitlerinin oleik asit oranı \%26.31-29.58 arasında olduğunu belirtmişlerdir. En yüksek oleik asit oranı Bravo çeşidinde elde edilirken, en düşük ise Atakişi (\%26.31) çeşidinde saptanmıştır. Linoleik asit oranı \%30.66-40.63 arasında değişim göstermiştir. Linoleik asit oranı en yüksek Gapsoy 16 (\%40.63) çeşidinde, en düşük ise Lider $(\% 30.66)$ çeşidinde saptanmıştır. Linolenik asit oranı \%9.55-11.25 arasında değișim göstermiştir. En yüksek Gapsoy 16 (\%11.25) çeşidinde, en düşük ise Bravo (\%9.55) çeşidinde saptanmıştır. Palmitik asit oranı \%10.88-12.54 arasında belirlenmiştir. Palmitik yağ asidi oranı en yüksek Asya ve Anp 2018 (\%12.54) çeşidinde, en düşük ise Planet $(\% 10.88)$ çeşidinde saptanmıştır. Stearik asit oranı \%7.23-8.25 arasında değişim göstermiştir. Stearik yağ asidi oranı en yüksek Gapsoy 16, Türksoy ve Planet genotiplerinde (sırasiyla, \%8.25, \%8.19 ve \%8.18), en düşük ise Lider (\%7.23) genotipinde saptanmıştır.

Soyada büyüme dönemleri ilerledikçe özellikle oleik ve palmitik asit oranlarında azalma olurken, linoleik asit içeriğinde ise artış meydana gelmektedir [38]. [39], özellikle sıcaklık artışlarının enzimler üzerinde önemli bir etkisinin olduğunu ve oleayl-PC desaturaz ve linoleayl-PC desaturaz gibi oleik asitten linoleik ve linolenik asidin sentezlenmesini katalize eden enzimlerin aktivitesinde azalma meydana geldiği bu nedenle artan sıcaklık artışı özellikle bitkilerde linoleik ve linolenik asit sentezi üzerine etkisi olumsuz, oleik asit sentezi üzerine ise etkisinin olumlu olduğunu bildirmişlerdir. [40], tohum oluşum ve gelişmesi dönemlerinde gece ve gündüz sıcaklık farklılığından dolayı, yağ, protein oranı ile yağ asidi ve amino asit bileşimi üzerine etkilerini belirlemek amacıyla yapmış olduğu araştırmada, yağ asitleri bileşimi sıcaklıktan önemli derecede etkilendiğini, linolenik ve linoleik asit oranları sıcaklık artıkça önemli derece azalırken, oleik asit miktarında artış, palmitik ve stearik ait miktarlarında ise bir değişimin olmadı̆̆ını belirtmişlerdir. [41], soyada enlem derecesindeki farklılığın özellikle linoleik ve linoleik asit içeriği üzerinde etkili olduğunu ve enlem derecesi yükseldikçe arttığını fakat oleik asit içeriğinin ise azaldığ 1 tespit edilmiştir. [42], ABD'nin güneyinde soya çeşitlerinde linolenik asit oranının düşük, kuzeyinde ise soya çeşitlerinde oleik asit oranının daha yüksek olduğunu belirtmişlerdir. Uzun olgunlaşma grubunda yer alan soya çeşitlerinde oleik asit oranı azalırken, linoleik asit ve linolenik asit oranlarının artığ belirlenmiştir [41]. [5], soya yă̆ ve yă̆ asitleri içeriğinin çeşitlere göre farklılık gösterdiğini, soya tohumları \% 18-24 oranında yağ, \% 44-62 Linoleik asit, \%19-30 Oleik asit, \%7-14 Palmitik asit , \% 4-11 Linolenik asit, ve \% 1.4-5.5 Stearik asit gibi önemli yă asitlerini ihtiva ettiğini bildirmektedir. [42], soya yağındaki oleik asit oranının $\% 15-33$, linoleik asit oranının \%43-56, linolenik asit oranının \% 5-11 ve doymuş yağ asitleri oranının ise \%11-26 arasında değişim gösterdiğini bildirmişlerdir. [43], soya yağının bileşiminde; \%36.1-61.9 linoleik asit, \%16.6-47.8 oleik asit, \%3.6-4.5 stearik asit, \% 9.2-13.1 palmitik asit ve \% 3.0-7.7 linolenik asit olduğunu belirtmişlerdir.

\subsection{Korelasyon analizi}

Bitki boyu özelliği bitki sayısı, meyve sayısı ve tane verimi arasında olumlu ve önemli ilişki olduğu görülmüştür. Tane verimi ile linolenik arasında olumlu ve önemli ilişki belirlenirken oleik ve palmitik arasında ise olumsuz ilişki olduğu belirlenmiştir. Palmitik asit ile tohum sayısı, 100 tane ağırlığı ve tane verimi arasında olumsuz ve önemli bir korelasyon olduğu belirlenmiştir (Tablo 4). 
Tablo 4. İncelenen özellikler arası korelasyon analizi

\begin{tabular}{|c|c|c|c|c|c|c|c|c|c|c|c|c|c|}
\hline & BB & İMY & BS & MS & $\mathrm{TS}$ & $100 \mathrm{TA}$ & TV & Yağ & Protein & Oleik & Linoleik & Linolenik & Palmitik \\
\hline BB & 1.00 & & & & & & & & & & & & \\
\hline İMY & 0.27 & 1.00 & & & & & & & & & & & \\
\hline $\mathrm{BS}$ & $0.43 * *$ & $0.37 *$ & 1.00 & & & & & & & & & & \\
\hline MS & $0.47 * *$ & 0.19 & 0.17 & 1.00 & & & & & & & & & \\
\hline $\mathrm{TS}$ & 0.64 & 0.25 & 0.22 & 0.86 & 1.00 & & & & & & & & \\
\hline $100 \mathrm{TA}$ & -0.01 & -0.12 & -0.19 & -0.14 & -0.22 & 1.00 & & & & & & & \\
\hline $\mathrm{TV}$ & $0.50 * *$ & 0.27 & $0.46 * *$ & 0.15 & 0.29 & 0.11 & 1.00 & & & & & & \\
\hline Yağ oran 1 & 0.11 & 0.26 & 0.19 & 0.26 & 0.18 & 0.01 & 0.19 & 1.00 & & & & & \\
\hline Protein & 0.09 & -0.46 & \begin{tabular}{|c|}
-0.42 \\
\end{tabular} & 0.23 & 0.29 & 0.11 & -0.07 & \begin{tabular}{|l|}
-0.46 \\
\end{tabular} & 1.00 & & & & \\
\hline Oleik & -0.24 & -0.25 & $-0.40 *$ & $-0.54 * *$ & $-0.52 * *$ & 0.36 & $-0.51 * *$ & $-0.51 * *$ & 0.12 & 1.00 & & & \\
\hline Linoleik & 0.00 & -0.13 & -0.02 & 0.15 & 0.15 & 0.17 & 0.48 & 0.21 & 0.02 & -0.45 & 1.00 & & \\
\hline Linolenik & 0.45 & 0.36 & 0.58 & 0.38 & 0.45 & -0.51 & $0.34 * *$ & 0.00 & -0.06 & $-0.56 * *$ & $-0.34 *$ & 1.00 & \\
\hline Palmitik & -0.60 & $-0.32 *$ & -0.14 & -0.27 & $-0.38 *$ & $-0.47 * *$ & $-0.33 *$ & 0.10 & -0.25 & -0.16 & 0.01 & -0.01 & 1.00 \\
\hline Stearik & 0.74 & $0.46^{* * *}$ & $0.39 *$ & $0.46^{* * *}$ & 0.51 & 0.03 & 0.27 & 0.24 & 0.01 & -0.22 & $-0.38 *$ & $0.55^{* *} *$ & -0.64 \\
\hline
\end{tabular}

*\% 5 ve **\% 1seviyesinde önemlidir. BB: bitki boyu, İMY:ilk meyve yüksekliği, BS:boğum sayısı, MS:meyve sayıs1, TS:tohum sayıs1, 100 TA:100 tohum ağırlı̆̆ 1 , TV: tane verimi

\section{SONUÇ}

Şırnak ilinde sulanabilir tarım alanlarında soya bitkisinin ikinci ürün olarak yetiştiriciliğine uygunluğu ve çeşit tespitinin belirlenmesi amaciyla yürütülen çalışmada; tane verimi yönünden Gapsoy 16, Planet ve Lider çeşitleri ön plana çıkmıştır. Blaze ve Gapsoy16 çeşitleri yüksek protein ihtiva ederken, Atakişi çeşidi en yüksek yağ oranına sahip olmuştur. Oleik asit içeriği Bravo çeşidinden, linoleik asit içeriği ise Lider çeşitlerinde belirlenmiştir. Dünya soya verim ortalaması $249 \mathrm{~kg} \mathrm{da}^{-1}$ olduğu dikkate alınırsa, verim bakımından yaklaşık olarak dünya ortalamasının iki katına ulaşabilen soya çeşitlerine sahip oluşumuzdan dolayı, soya tarımının Şırnak ilinde yapılabileceğinin bir göstergesidir. Bu nedenle araştırmada kullanılan soya çeşitlerin, yetişme süresi ve verim değerleri bakımından Şırnak ili koşullarında ikinci ürün olarak başarılı bir şekilde yetiştiriciliğinin yapılabileceği ve Lider, Gapsoy 16 ve Planet çeşitlerinin ise en uygun çeşit olduğu kanısına varılmıştır.

\section{Teşekkür}

Ekonomik desteklerinden dolayı T.C Sanayi ve Teknoloji Bakanlığı Güneydoğu Anadolu Projesi Bölge Kalkınma İdaresi Başkanlığı ve Şırnak Üniversitesi Rektörlüğüne teşekkürler.

\section{KAYNAKLAR}

[1] FAO, Birleşmiş Milletler Gıda ve Tarım Örgütü. [Internet] FAOSTAT. $2020 \quad$ [Erişim tarihi:10.02.2020]Erişim:http://www.fao.org/faost at/en/\#data 2020.

[2] TÜİK, İstatistik Bölümü [Internet]. 2020 https://data.tuik.gov.tr/Bulten/Index?p=BitkiselUretim-Istatistikleri-2017-24581

[3] İlker E, Tatar Ö. Gökçöl A. Konvansiyonel ve organik tarım koşullarında bazı soya çeşitlerinin performansları. Ege Üniversitesi Ziraat Fakültesi Dergisi, 2010;47(1):87-96.

[4] İşler N, Söğüt T, Çalışkan ME. Bazı soya çeşitlerinin Diyarbakır Bölgesi II. ürün koşullarındaki önemli tarımsal ve bitkisel özelliklerinin belirlenmesi, Mustafa Kemal Üniversitesi Ziraat Fakültesi Dergisi, 1997;2(2): 81-89.

[5] Arığlu H. Yağ Bitkileri Yetiştirme ve Islahı, Ç.Ü. Ziraat Fakültesi Ders Kitapları Yayın No: A70, Ç.Ü. Ziraat Fakültesi Ofset Atölyesi, Adana, 2007. p. 204.

[6] Yılmaz A, Beyyavaş V, Cevheri İ, Haliloğlu H. Harran ovası ekolojisinde ikinci ürün olarak yetiştirilebilecek bazı soya (Glycine max. L. Merrill.) çeşit ve genotiplerinin belirlenmesi, Harran Üniversitesi Ziraat Fakültesi Dergisi, 2005;9 (2):55-61.

[7] Beyyavas V, Haliloglu H, Yilmaz A. The effect of different sowing times on yield and yield components in second crop soybean cultivation. J. Agric. Fac. Harran University, 2007;11(3/4):2332.

[8] İlker E. Performances of soybean [Glycine Max (L.) Merr.] advanced lines grown in second cropping under mediterranean climatical conditions of western Turkey. Turkish Journal of Field Crops. 2017; 22(1):104-107.

[9] Bakal H, Gulluoglu L, Onat B, Arioglu H. The effect of growing seasons on some agronomic and quality characteristics of soybean varieties in Mediterranean Region in Turkey. Turkish Journal of Field Crops. 2017; 22(2):1 87-196.

[10] Arioglu HH. Oil crops growing and breeding. Cukurova University Faculty Of Agriculture General Publication, No:220, Textbook No: A-70. 1999.

[11] Öztürk F. The evaluation of the yield and yield components of seven soybean (Glycine Max. L. Merill.) genotypes grown as a second crop under Sirnak condition, Int $\mathrm{J}$ Agric Environ Food Sci. 2019;3(2):54-57.

[12] Gunes A. Effects of different nitrogen doses and application time on yield and yield components of soybean (Glycine Max (L.) Merrill) cultivated as second crop. Msc Thessis, Harran Unıversity, Institute of Natural and Applied Science, Şanlıurfa, Turkey. 
[13] Yaver S, Pasa C. A research on the yield criteria of some soybean varieties in Tekirdağ conditions, Hatay, 19-22 October 2009, Turkey VIII. Field Crops Congress, V(1), p.197-200.

[14] Bakoğlu A, Ayçiçek M. Elazığ şartlarında soya fasulyesinin (Glycine max L.) tarımsal özellikleri ve tohum verimi, Firat Üniversitesi Fen ve Müh. Bilimleri Dergisi. 2005;17(1): 52-58

[15] Karasu A, Öz M, Göksoy AT. Bazı Soya Fasulyesi [Glycine max (L.) Merill] Çeşitlerinin Bursa Koşullarına Adaptasyonu Konusunda Bir Çalışma, Uludağ Üniversitesi Ziraat Fakültesi Dergisi, 2002;16 (2): 23-34.

[16] Board JE, Hall W. Premature flowering in soybean yield reductions at nonoptimal planting dates as influenced by temperature and photoperiod, Agron. J. 1984;76: 700- 704.

[17] Yılmaz HA. Kahramanmaraş ekolojisinde farklı ekim sıklıklarının iki soya (Glycine max (L.) Merrill) çeşidinde, verim ve verim unsurlarına etkisi, Turkish Journal of Agriculture and Forestry, 1999;(23): 223-232.

[18] Yilmaz N. The effects of seed rate on yield and yield components of soybean (Glycine max L. Merill), Pakistan Journal of Biological Sciences. 2003;6(4): 373-376.

[19] Yilmaz A, Beyyavas V, Cevheri I, Haliloglu H. Determination of some soybean (Glycine Max. L. Merrill.) varieties and genotypes which can be grown as second crop in Harran plain ecology, J. Agric. Fac. Harran University. 2005;9(2):55-61.

[20] Söğüt T, Öztürk F, Temiz MG. Farklı olgunlaşma grubuna dahil bazı soya (Glycine max L.) çeşitlerinin ana ve ikinci ürün koşullarındaki performanslarının karşılaştırılması, Antalya, 5-9 Eylül 2005, Türkiye VI. Tarla Bitkileri Kongresi, Cilt I, p. 393-398.

[21] Erenstein, O. Smallholder conservation farming in the tropics and sub-tropics aguide to the development and dissemination of mulching with crop residues and cover crops, Agriculture, Ecosystems and Environment. 2003;100:17-37.

[22] Daneshmand A, Yazdanpanah M, Koochaksaraee HNK, Yasari E. Investigation of the effects of plant density and planting date on the quantitative and qualitative yields of two advanced soybean lines, International Journal of Biology. 2013; 5(3):37.

[23] Bruin J, Pederson P. Soybean seed yield response to planting date and seeding rate in the upper midwest, Agronomy Journal. 2008;100:696- 703.

[24] Coulter JA, Van Roekel RJ. Agronomic responses of cornt to planting date and plant density, Agronomy Journal. 2011;(103):1414-1422.

[25] Li Y, Du M, Zhang Q, Wang G, Jin J, Herbert S, Liu X. Planting date influences fresh pod yield and seed chemical compositions of vegetable soybean, Horticultural Science. 2014; 49(11):1376-1380.

[26] Wilson RF. Seed composition soybeans: improvement, production, and uses (Ed. By H.R. Boerma and J.E.Specht) 3rd edition, Chapter 13, p.621-677, Agronomy Series No:16. Madison,Wisconsin, 2004, 1144.

[27] Güllüoğlu L, Kurt C, Arığlu HH, Onat B. İkinci ürün koşullarında bazı soya [Glycine max (L.) Merr] genotiplerinin (çeşit ve hatlar) önemli tarımsal ve kalite özelliklerinin belirlenmesi, Ç.Ü.Z.F. Yıllığı. 2010;25(1): 41-52.

[28] Güngör H, Üstün A. Konya ekolojisinde iki farklı sıra aralığının bazı soya (Glycine max.(L.) Merill) genotiplerinde verim ve bazı verim unsurlarına etkisi. Gaziosmanpaşa Üniversitesi Ziraat Fakültesi Dergisi, 2015;32(2):100-106.

[29] $\mathrm{Hu} \mathrm{MX}$, Wiatrak P. Effect of planting date on soybean growth, yield, and grain quality, Agron. J. 2012;104:785-790.

[30] Kumar V, Rani A, Pandey V, Mande P, Chauhan GS. Compositional traits of soybean seeds as influenced by planting date in India. Exp. Agric. 2006;42:19-28.

[31] Muhammad A, Khalil SK, Marwat KB, Khan AZ, Khalil IH, Amanullah J, Arifullah S. Nutritional quality and production of soybean land races and improved varieties as affected by planting dates. Pak. J. Bot. 2009;41:683-689.

[32] Tremblay GJ, Beausoleil JM, Filion P, Saulnier M. Response of three soybean cultivars to seeding date, Can. J. Plant Sci. 2006;86:10711078.

[33] $\mathrm{Hu}$ M. Effects of late planting dates, maturity groups and management systems on growth, development and yield of soybean in South Carolina. 2013. All Thesis. Paper 1593.

[34] Kane MV, Steele CC, Grabau LJ, MacKown CT, Hildebrand DF. early-maturing soybean cropping system. 111: protein and oil contents and oil composition, Agron. J. 1997;89:464-469.

[35] Egli BD, Bruening WP. Potential of earlymaturing soybean cultivars in late plantings, Agronomy Journal. 2000;(92):532-537.

[36] Asanome N, Ikeda T. Effect of branch direction's arrangement on soybean yield and yield components, Journal of Agronomy and Crop Science, 1998;181(2):95-102.

[37] Trawatha S, TeKrony D M, Hildebrand D F. Lipoxygenase activity and C6-Aldehyde formation in comporasion to Germination and vigor during soybean seed development,Crop Science. 1993;(33): 1337-1344.

[38] Broun P, Somerville C. Accumulation of ricinoleic, lesquerolic and densipolic asit an seeds to transgenic arabidopsis plants that express a fatty acyl hdroxlase cdna from castor bean, Plant Phsiology. 1997;113: 933-942.

[39] Wolf RB, Cavins JF, Kleiman R, Black LT. Effect of temperature on soybean seed constituents: oil, protein, fatty acids, amino acids and sugars, J. of the American Oil Chemists' Society. 1982;59(5):230-232.

[40] Cuniberti MB, Herrero RM, Martinez MJ, Silva M, Baigorri HE, Para R, Weilenmann E, Masiero B. Fatty asits composition of the argention soybean evaluated in different latitudes and 
planting dates. VII. February 29 March 5, World Soybean Research Conference, 228-229.

[41] Cherry JH, Bishop L, Hasegawa PM. Differerences in fatty asitd composition of soybean seed produced in northern and southern aeas of the USA. Phytochemistry 1985; (24): 237 241.

[42] Collins FI, Sedgwick VE. Fatty asit composition of several varieties of soybeans, J.of the Amerian Oil Chemists Society. 1959;36(12):641-644.

[43] Mounts TL, Warner K, List GR, Kleiman R, Fehr WR, Hammond EG, Wilcox JR. Effect of altered fatty acid composition on soybean oil stability, Journal of the American Oil Chemists' Society. (1988);65(4):624-628. 